\title{
INFLUÊNCIA DO MEIO DE CULTURA E CONCENTRAÇÃO DE AGAR NO CRESCIMENTO E DESENVOLVIMENTO DE PLÂNTULAS DE CAFÉ ORIUNDAS DA EMBRIOGÊNESE SOMÁTICA DIRETA
}

\author{
INFLUENCE OF THE CULTURE MEDIUM AND AGAR CONCENTRATION IN \\ THE GROWTH AND DEVELOPMENT OF PLANTLETS COFFEE FROM DIRECT \\ SOMATIC EMBRYOGENESIS
}

\author{
Juliana Costa de REZENDE ${ }^{1}$ \\ Moacir PASQUAL ${ }^{2}$ \\ Samuel Pereira de CARVALHO² \\ Alba Regina PEREIRA ${ }^{3}$ \\ Fabíola VILLA ${ }^{1}$
}

\section{RESUMO}

Um importante método de propagação in vitro de plantas de Coffea arabica é a embriogênese somática. Objetivouse com esse trabalho, avaliar a influência de meios de cultura e de concentrações de ágar no crescimento de plântulas de Coffea arabica L. cv. Rubi. Os experimentos foram conduzidos no Laboratório de Cultura de Tecidos da Universidade Federal de Lavras, em 2005, em delineamento experimental inteiramente ao acaso, com 4 repetições e esquema fatorial $4 \times 5$. Os tratamentos foram constituídos de diferentes tipos de meios de cultura (MS; Knudson; WPM; White) e de diferentes concentrações de ágar $\left(0 ; 2 ; 4 ; 6\right.$ e $\left.8 \mathrm{~g} \mathrm{~L}^{-1}\right)$, que permaneceram por sessenta dias em sala de crescimento com irradiância em torno de 32 iM $\mathrm{m}^{-2} \mathrm{~s}^{-1}$ e fotoperíodo de $16 \mathrm{~h}$, sob temperatura de $25 \pm 1{ }^{\circ} \mathrm{C}$. As variáveis avaliadas foram: número de folhas, comprimento da parte aérea e massa fresca da plântula. Concluiu-se que o meio WPM apresentou maior eficiência para o desenvolvimento de plântulas de cafeeiro. Nestas, a concentração de $1,5 \mathrm{~g} \mathrm{~L}^{-1}$ de ágar proporciona massa fresca mais alta e maior comprimento da parte aérea. O maior número de folhas foi obtido na ausência de ágar.

Palavras-chave: Coffea arábica; cultura de tecidos; melhoramento genético.

\begin{abstract}
An important method of in vitro propagation of Coffea arabica plants is somatic embryogenesis. This work aimed to achieve the most adequate culture medium formulation and agar concentration for the plantlets growth of Coffea. arabica L. cv. Rubi from direct somatic embryogenesis. The experiment was carried out at the Tissue Culture Laboratory of Federal University of Lavras, in 2005, in randomized block, with four replications, and factorial $4 \times 5$. It was evaluated the influence of different types of culture media (MS; Knudson; WPM; White) and different concentration agar $\left(0 ; 2 ; 4 ; 6\right.$ and $\left.8 \mathrm{~g} \mathrm{~L}^{-1}\right)$. The experiment was maintained for 60 days in a growth room under light intensity of $32 \mu \mathrm{Mol} \mathrm{m}^{-2} \mathrm{~s}^{-1}, 25 \pm 1{ }^{\circ} \mathrm{C}$ photoperiods of 16 hours. The characteristics evaluated were: number of leaves, length of the aerial part and fresh mass weight of the plantlets. The results indicated the WPM culture medium, presented larger efficiency for development plantlets of Coffea arabica. The concentration of $1,5 \mathrm{~g} \mathrm{~L}^{-1}$ of agar provided the best fresh mass weight as well as the biggest length of the aerial part. The largest number of leaves was obtained in the absence of agar.
\end{abstract}

Key-words: Coffea Arabica; tissue culture; genetic improvement.

\footnotetext{
${ }^{1}$ Eng. Agrônoma Doutoranda em Agronomia, Produção Vegetal. Universidade Federal de Lavras (UFLA) Departam. de Agricultura . CP3037. CEP37200000 E-mail juliana ufla@yahho.com.br, fvilla@libero.it. Bolsistas Capes

${ }^{2}$ Eng. Agrônomo Dr. Prof Adjunto do Departamento de Agricultura da UFLA. E-mail mpasqual@ufla.br (autor para correspondência), samuelpc@ufla.br

${ }^{3}$ Eng. Agrônoma Doutoranda do Instituto de Pesquisas Jardim Botânico. RJ. E-mail: albapereira@bol.com.br. Bolsista Capes.
} 
REZENDE, J.C. et al. Influência do meio de cultura e concentração...

\section{INTRODUÇÃO}

O desenvolvimento científico e tecnológico da cafeicultura vem assegurando alta produtividade e lucratividade, contribuindo de maneira decisiva para a industrialização do país, graças ao capital reunido com as exportações do produto. Neste contexto, o melhoramento genético do cafeeiro tem contribuído muito para este desenvolvimento, incorporando por meio de cruzamentos ganhos genéticos para produtividade e outras características de interesse agronômico.

A introdução de métodos biotecnológicos para auxiliar os programas de melhoramento genético tem se mostrado bastante útil, principalmente em culturas perenes, como é o caso do cafeeiro (DUBLIN, 1991; BIEYSSE et al., 1993; ZAMARRIPA, 1993; BERTHOULY e MICHAUXFERRIERE, 1996; CORDEIRO, 1999; MACIEL et al., 2003; PEREIRA et al., 2007; REZENDE, 2005). Um importante método de propagação in vitro de plantas de Coffea arabica é a embriogênese somática, que apresenta um grande potencial a ser explorado.

Os fatores que mais freqüentemente determinam o sucesso da propagação in vitro são a origem do explante e o meio nutritivo onde são cultivados. Diversas formulações de meio de cultura têm sido empregadas na cultura in vitro, as quais diferem entre si basicamente em relação à concentração dos sais. O meio de cultura MS (MURASHIGE e SKOOG, 1962) é o mais utilizado na propagação in vitro de $C$. arabica, promovendo resultados positivos na multiplicação de segmentos nodais, desenvolvimento de embriões e indução de embriogênese somática em explantes foliares (MACIEL et al., 2003; PEREIRA et al., 2007; REZENDE, 2005).

Para outras espécies vegetais, usa-se também o meio básico WPM (Wood Plant Médium) de LLOYD e MCCOWN (1980), o meio básico Knudson (modificado por ARDITTI, 1967) e o meio básico WHITE (1943), entre outros. O meio WHITE (1943) foi utilizado por muito tempo como meio básico para a cultura de uma grande variedade de espécies (CALDAS et al., 1998; RIBEIRO et al., 2003).

Entretanto, para cada tipo de explante, espécie e cultivar, o meio de cultura mais adequado e eficiente deve ser determinado experimentalmente. RIBEIRO et al. (2003), trabalhando com embriões zigóticos da cultivar Rubi, obtiveram maior comprimento da parte aérea utilizando o meio MS, em relação aos meios WPM, White e Knudson. Em estudos com Pterodon pubescens Benth. (Sucupira Branca) realizados por COELHO et al. (2001), segmentos nodais foram melhor estabelecidos em meio WPM, quando comparados com o meio MS. BERTOLUCCI (1999) verificou que brotações de Tournefortia cf paniculata (Marmelinho), atingiram maior tamanho quando cultivados em meio WPM do que em meio MS.

O ágar é o agente geleificante comumente utilizado na solidificação dos meios de cultura (SINGHA, 1984; GEORGE, 1993). GEORGE (1993) atribui isto à vantagem de formar um colóide quando adicionado à água, tornando-se líquido a $100{ }^{\circ} \mathrm{C}$ e solidificando-se a $45^{\circ} \mathrm{C}$, mantendo-se estável nas temperaturas de incubação. Além do mais não reage com os constituintes do meio. Devido à presença de inibidores orgânicos e inorgânicos associados ao ágar (PIERIK, 1987), tanto a qualidade como a concentração de agar, afetam as características químicas e físicas do meio de cultura, e conseqüentemente as respostas do explante in vitro (ROMBERGER e TABOR, 1971).

As concentrações mais elevadas de ágar dificultam o contato entre o explante e o meio, limitando a absorção de compostos (PIERIK, 1987), fato este também observado por PAIVA et al. (1999) em microestacas de crisântemo (Dendrathema grandifolia uveleu). Por outro lado, PASQUAL et al. (2002) e RIBEIRO et al. (1999), trabalhando respectivamente com embriões imaturos de tangerina 'Poncã' e laranja 'Natal' em meio MS, obtiveram o maior número de folhas utilizando alta concentração de ágar.

Dessa forma, objetivou-se com esse trabalho, avaliar a influência de diferentes meios de cultura e de concentrações de ágar no desenvolvimento de plântulas de Coffea arabica L. cv Rubi.

\section{METODOLOGIA}

Os experimentos foram conduzidos no Laboratório de Cultura de Tecidos Vegetais do Departamento de Agricultura da Universidade Federal de Lavras, MG. Inicialmente foram induzidos embriões somáticos via embriogênese somática direta, a partir de explante foliar de Coffea arabica L. cv. Rubi oriundas de cultivo in vitro de embrião zigótico. Os embriões somáticos foram induzidos em meio com metade dos sais de MS, com adição de 20,0 $\mathrm{mg} \mathrm{L}^{-1}$ de ácido giberelico $\left(\mathrm{GA}_{3}\right), 6,0 \mathrm{mg} \mathrm{L}^{-1} \mathrm{de}$ cinetina, $8,0 \mathrm{mg} \mathrm{L}^{-1}$ de ácido naftaleno acético (ANA), $100 \mathrm{mg} \mathrm{L}^{-1}$ de caseína hidrolisada e $400 \mathrm{mg} \mathrm{L}^{-1} \mathrm{de}$ extrato de malte. Os tubos foram mantidos durante 150 dias sob condições de obscuridade, com temperatura de $25 \pm 1{ }^{\circ} \mathrm{C}$. Estes embriões foram individualizados em tubos de ensaio e mantidos, durante 150 dias, em meio MS, até que houvesse o desenvolvimento de plântulas de Coffea arabica cv. Rubi com 1 até $1,5 \mathrm{~cm}$ de comprimento, e posteriormente usados para a realização dos experimentos deste estudo.

Os tratamentos consistiram da combinação de quatro diferentes tipos de meio de cultura [MURASHIGE e SKOOG (1962); Knudson (ARDITTI, 1967); WPM (LLOYD e MCCOWN, 1980), White (WHITE, 1943)] e cinco concentrações de ágar ( $0 ; 2$; $4 ; 6$ e $\left.8 \mathrm{~g} \mathrm{~L}^{-1}\right)$.

$\mathrm{O} \mathrm{pH}$ do meio foi ajustado para $5,8 \pm 0,1$, utilizando $\mathrm{NaOH} 0,5$ e $0,1 \mathrm{~mol} \mathrm{~L}^{-1}$ ou $\mathrm{HCl} 0,5$ e 0,1 mol L-1 e distribuído em tubos de ensaio, de $16 \mathrm{X}$ $150 \mathrm{~mm}$, cada um recebendo $15 \mathrm{~mL}$ do mesmo. Os tubos foram vedados com tampas plásticas translúcidas e autoclavados a $121^{\circ} \mathrm{C}$ e $0,1 \mathrm{MPa}$, por 
$20 \mathrm{~min}$. Nos tratamentos referentes as combinações da concentração de $0 \mathrm{~g} \mathrm{~L}^{-1}$ de ágar foi colocado, no tubo de ensaio, um disco de papel de filtro com um orifício no meio, onde foram inseridos os explantes, de modo a dar sustentação a estes.

Os tubos foram vedados com parafilme e mantidos em sala de crescimento com irradiância em torno de $32 u \mathrm{M} \mathrm{m}^{-2} \mathrm{~s}^{-1}$ e fotoperíodo de $16 \mathrm{~h}$, sob temperatura de $25 \pm 1{ }^{\circ} \mathrm{C}$. O delineamento experimental utilizado foi inteiramente casualizado, com quatro repetições e três tubos por parcela, cada tubo contendo um explante.

Aos sessenta dias após a instalação do experimento, as plântulas foram avaliadas quanto ao número de folhas, comprimento da parte aérea $e$ massa fresca das plântulas. Os dados obtidos foram submetidos à análise de variância para dados desbalanceados. Utilizou-se o procedimento GLM disponível no aplicativo computacional $S{ }^{\circledR}$ (SAS, 1990). Por não apresentar normalidade dos resíduos, os dados relativos ao comprimento da parte aérea foram transformados para raiz quadrada $(x)$ e aqueles relativos a massa fresca foram transformados para $(x+1)^{1 / 5} / 0,2$.

\section{RESULTADOS E DISCUSSÃO}

Houve efeito significativo dos meios de cultura estudados para o número de folhas, comprimento da parte aérea e massa fresca das plântulas (Tabela 1). A concentração de ágar também mostrou-se significativa em relação a estas duas últimas características. A interação entre os fatores influenciou significativamente, o número de folhas e a massa fresca das plântulas.

Utilizando-se o meio MS, observou-se o decréscimo do número de folhas (média de 1,34 folhas) (Figura 1) até a concentração de 1,69 $\mathrm{g} \mathrm{L}^{-1} \mathrm{de}$ ágar, havendo, a partir desta concentração, um incremento no número de folhas até a concentração de $6,71 \mathrm{~g} \mathrm{~L}^{-1}$ de ágar (média de 5,38 folhas). Esses resultados seguem a mesma tendência daqueles obtidos por PASQUAL et al. (2002) e RIBEIRO et al. (1999), trabalhando, respectivamente com embriões imaturos de tangerina 'Poncã' e laranja 'Natal' em meio MS, que também obtiveram o maior número de folhas utilizando alta concentração de ágar $(8,5 \mathrm{~g}$ $\mathrm{L}^{-1}$ de ágar com $\mathrm{pH}$ ajustado para 4,7).

TABELA 1 - Análise de variância dos dados relativos ao número de folhas (NF), comprimento da parte aérea (CPA) e massa fresca (MF) das plântulas de C. arabica L. cv. Rubi cultivadas em diferentes concentrações de ágar e diferentes meios de cultura. UFLA, Lavras, MG, 2005.

\begin{tabular}{lllcl}
\hline Fonte de Variação & \multicolumn{4}{c}{$\mathrm{QM}$} \\
\cline { 2 - 5 } & $\mathrm{GL}$ & $\mathrm{NF}$ & $\mathrm{CPA}(\mathrm{cm})$ & $\mathrm{MF}(\mathrm{g})$ \\
\hline Meio & 3 & $44,4934^{\star}$ & $0,2386^{*}$ & $4,3466^{\star *}$ \\
Ágar & 4 & 20,1864 & $0,3008^{\star}$ & $4,7701^{\star *}$ \\
Meio x Ágar & 12 & $25,3185^{\star}$ & 0,6179 & $0,5356^{\star}$ \\
Erro & 180 & 9,2219 & 0,0351 & 0,2692 \\
\hline CV (\%) & & 82,52 & 15,68 & 6,20 \\
\hline
\end{tabular}

*, ${ }^{\star \star}$ Significativos a $1 \%$ e $5 \%$, respectivamente, pelo teste $\mathrm{F}$.

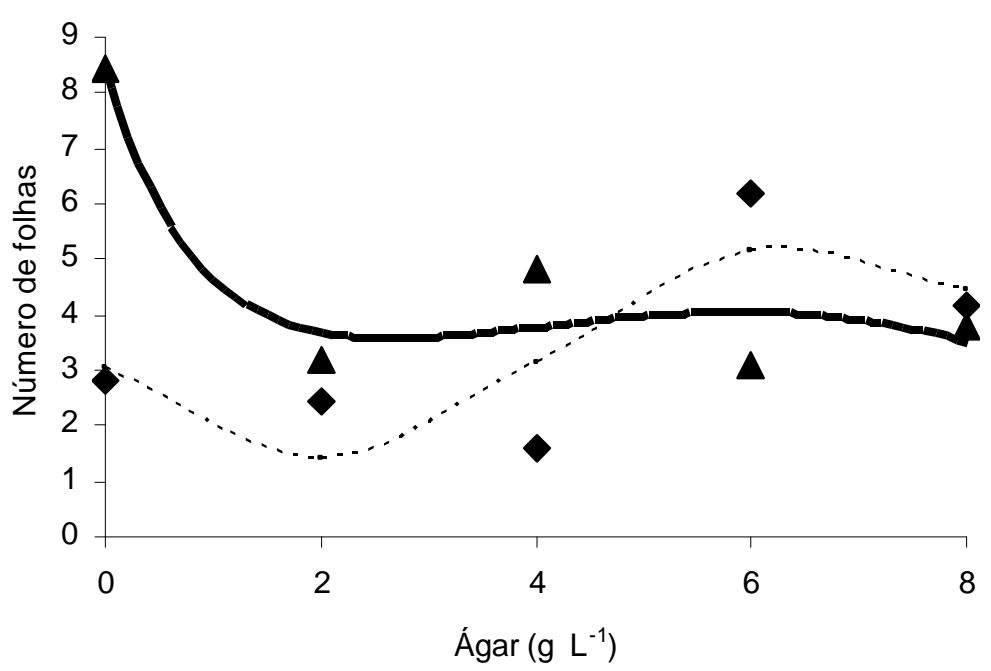

$$
\begin{gathered}
\mathrm{Y}_{\text {White; }} \mathrm{Y}_{\text {Knudson }}=\mathrm{ns} \\
\boldsymbol{\Delta}(-) \mathrm{Y}_{\mathrm{MS}}=3,05795-2,20376 \mathrm{X}+0,81247 \mathrm{X}^{2}-0,06443 \mathrm{X}^{3} \quad \mathrm{R}^{2}=0,6449 \\
\mathrm{Y}_{\text {WPM }}=8,39142-4,22743 \mathrm{X}-0,22073 \mathrm{X}^{2}-11,19553 \mathrm{LN}(\mathrm{X}+1) R^{2}=0,8819
\end{gathered}
$$

FIGURA 1 - Número de folhas de plântulas de $C$. arabica L. cv. Rubi cultivadas em diferentes concentrações de ágar acrescidas nos meios de cultura MS e WPM. UFLA, Lavras, MG, 2005. 
REZENDE, J.C. et al. Influência do meio de cultura e concentração...

Verificou-se maior formação de pares de folhas com a utilização do meio WPM na ausência de ágar, com média de 8,4 folhas e acima desta passou a haver decréscimo até a concentração de 2,67 $\mathrm{g} \mathrm{L}^{-1}$ de ágar (média de 3,54 folhas), apresentando um ligeiro aumento até a concentração de $5,90 \mathrm{~g} \mathrm{~L}^{-1}$ de ágar (com média de 4,02 folhas). Possivelmente, o aumento da concentração de ágar promoveu a elevação do potencial osmótico do meio WPM, dificultando a difusão dos nutrientes para os embriões e, conseqüentemente, reduzindo seu desenvolvimento. Meios líquidos possuem também a vantagem de preparo mais rápido e propiciam menor custo do que os meios sólidos (CALDAS et al.,1998; PASQUAL et al., 2002).
Vale ressaltar que ainda na Figura 1 que, com a utilização da concentração de $6 \mathrm{~g} \mathrm{~L}^{-1}$ de ágar, o meio MS apresentou maior número de folhas (media de 6,06 folhas) em relação ao meio WPM (média de 4,5 folhas). Esta concentração de ágar é usualmente utilizada no meio MS para inúmeras culturas.

O maior comprimento da parte aérea foi observado na concentração de $1,52 \mathrm{~g} \mathrm{~L}^{-1}$ de ágar (Figura 2), apresentando média de $1,31 \mathrm{~cm}$, havendo, a partir deste ponto, redução do comprimento com o incremento de concentrações de ágar. Esses resultados estão de acordo com aqueles obtidos por PIO et al. (2001) que, trabalhando com bananeira cv. Prata Anã, observaram maior altura da planta na concentração $1,75 \mathrm{~g} \mathrm{~L}^{-1}$ de ágar adicionado ao meio.

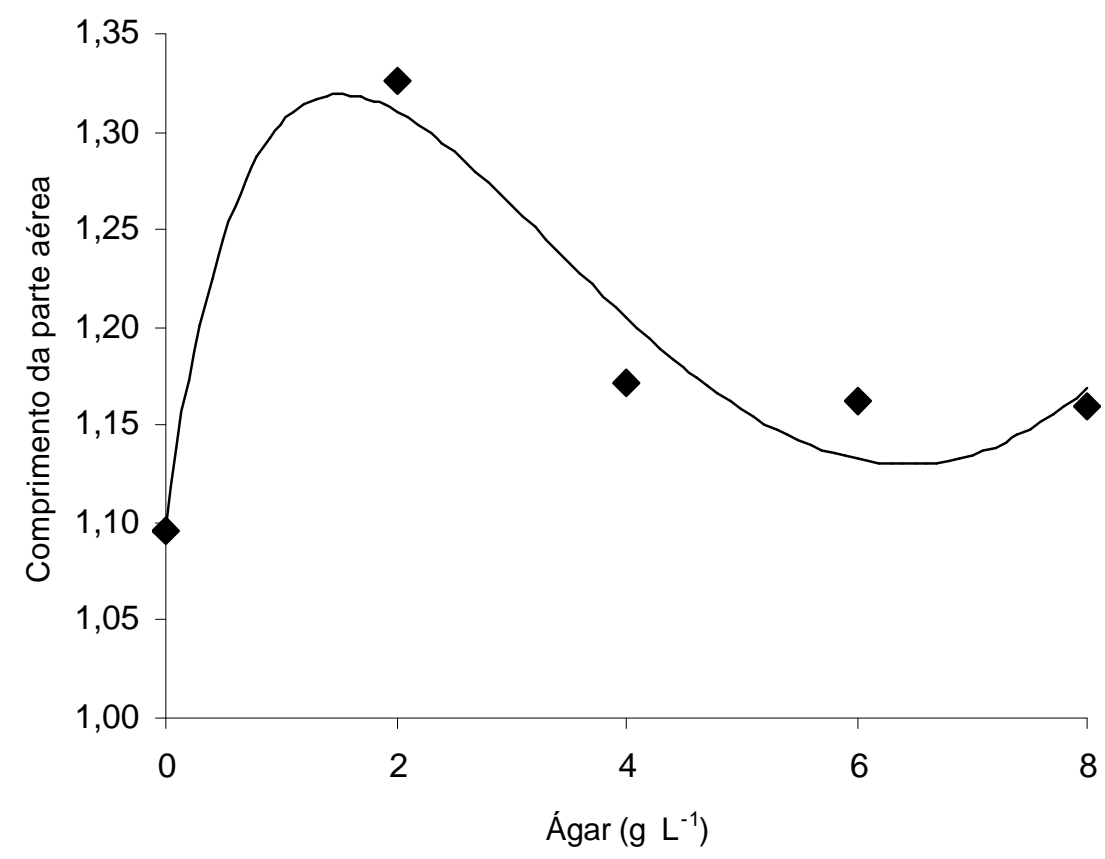

FIGURA 2 - Comprimento da parte aérea de plântulas de C. arabica L. cv. Rubi cultivadas em diferentes concentrações de ágar. UFLA, Lavras, MG, 2005. $0,85071 \mathrm{LN}(X+1) ; R^{2}=92,04 \%$.

A Figura 3 apresenta o comprimento da parte aérea das plântulas nos meios de cultura estudados. Os meios MS e WPM apresentaram efeito superior ao meio White, enquanto o meio Knudson foi estatisticamente semelhante aos demais. Esses resultados assemelham-se aos obtidos por JESUS et al. (2003), que verificaram que o comprimento da parte aérea de segmentos nodais de $C$. arabica $\mathrm{L}$. cv. Catuaí foi semelhante aos meios WPM e MS. Por outro lado, RIBEIRO et al. (2003), trabalhando com embriões zigóticos da cultivar Rubi, obteve melhor desenvolvimento de plântulas utilizando o meio MS em comparação aos meios Knudson, WPM e White.

Na Figura 4 observa-se que o meio WPM combinado à concentração $1,33 \mathrm{~g} \mathrm{~L}^{-1}$ de ágar apresentou maior massa fresca $(9,09 \mathrm{~g}$, dados transformados). As equações do gráfico apresentaram bom ajuste e mostram ainda que, quando utilizadas as concentrações de $0,77 \mathrm{~g} \mathrm{~L}^{-1} \mathrm{de}$ ágar no meio Knudson e de $1,58 \mathrm{~g} \mathrm{~L}^{-1}$ de ágar no meio White observa-se massa fresca de 8,09 e 8,57 $\mathrm{g}$, respectivamente (dados transformados). Observase ainda, que, concentrações maiores que $1,58 \mathrm{~g} \mathrm{~L}$ ${ }^{1}$ de ágar não proporcionaram aumento da massa fresca em todos os meios de cultura estudados.

O mesmo foi constatado com o ganho relativo de matéria fresca das culturas de ápices de brotações de kiwi (Actinidia chinenesis Planch) (MONETTE, 1986). Esses resultados corroboram com RIBEIRO et al. (1999) e PASQUAL et al. (2002), que obtiveram maior massa fresca em embriões de laranja 'Natal' e tangerina 'Poncã', respectivamente, na ausência de ágar. Não foram observadas diferenças significativas para massa fresca das plantas desenvolvidas no meio MS.

Embora para um crescimento adequado da maioria das espécies seja utilizada a concentração de 5 a $8 \mathrm{~g} \mathrm{~L}^{-1}$ de ágar, esse resultado não foi verificado 
REZENDE, J.C. et al. Influência do meio de cultura e concentração...

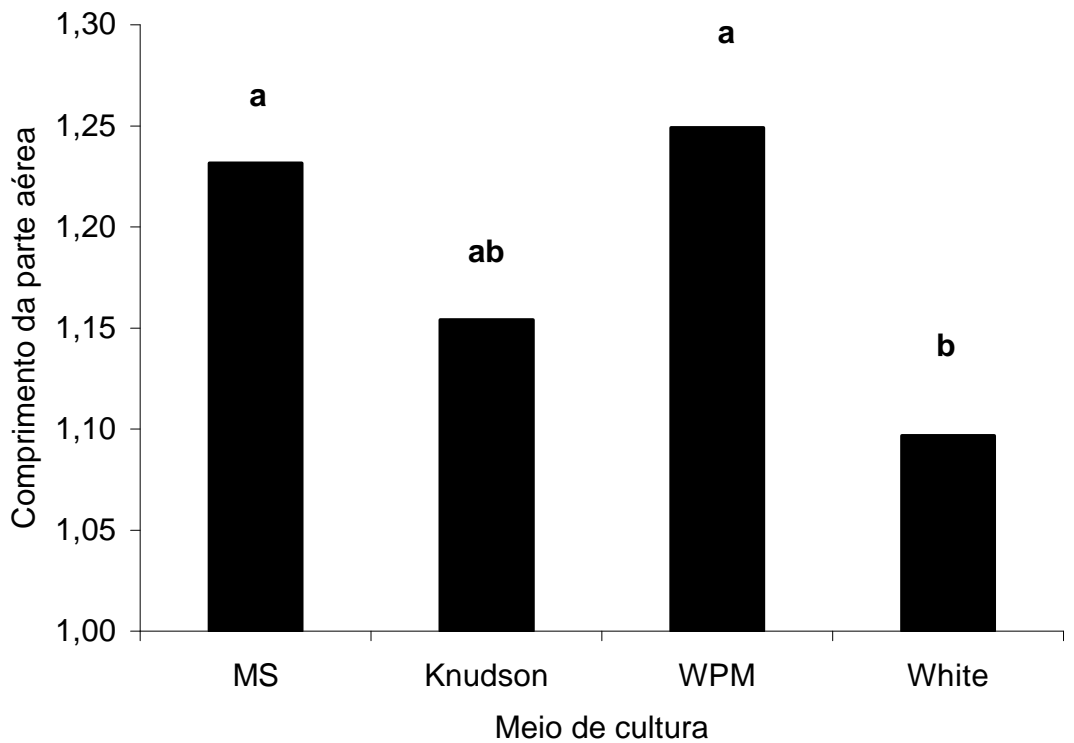

FIGURA 3 - Comprimento da parte aérea de plântulas de C. arabica L. cv. Rubi, cultivados em diferentes meios de cultura. UFLA, Lavras, MG, 2005. Médias com a mesma letra não diferem entre significativamente pelo Teste de Tukey a $1 \%$ de probabilidade.

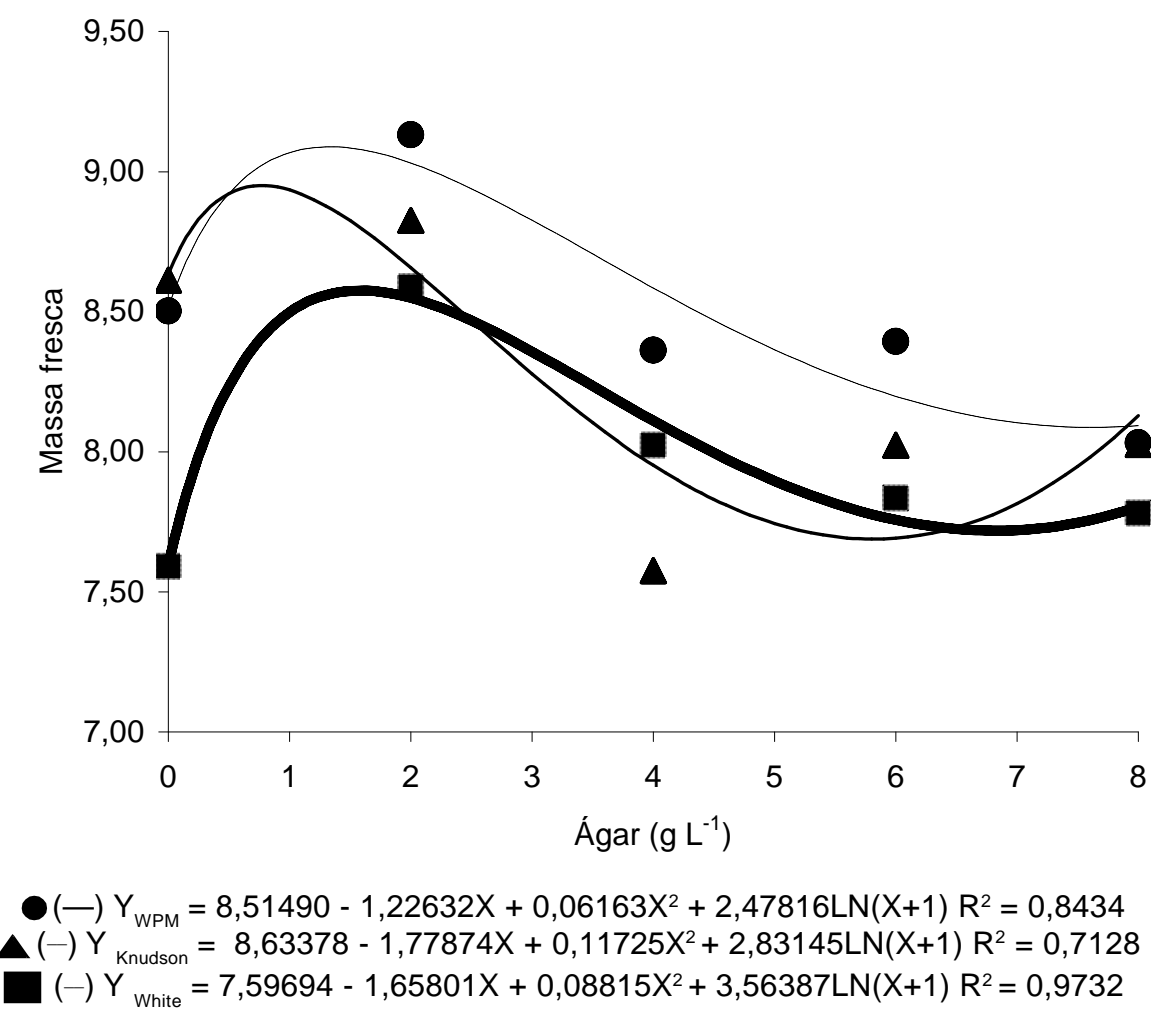

FIGURA 4 - Efeito de concentrações de ágar em diferentes meios de cultura na massa fresca de plântulas de C. arabica L. cv. Rubi. UFLA, Lavras, MG, 2005.

no presente trabalho, no qual, os melhores resultados obtidos na ausência ou com baixa concentração de ágar.

Tal comportamento pode indicar que plantas provenientes de embriões somáticos de café não encontram dificuldade para se desenvolver em meios líquidos ou com baixa concentração de ágar, devido à maior facilidade de absorção de nutrientes e de reguladores de crescimento e também ao maior contato basal (ROMBERGER e TABOR, 1971). Meios líquidos são mais homogêneos, visto que não se estabelece um gradiente de nutrientes, que normalmente ocorre nos meios sólidos. Além disso, qualquer exsudato proveniente do explante é mais 
REZENDE, J.C. et al. Influência do meio de cultura e concentração...

facilmente diluído do que em meio com ágar, evitando, o acúmulo de tais compostos tóxicos (PIERIK, 1987).

\section{CONCLUSÕES}

O meio de cultura WPM apresentou maior eficiência para o desenvolvimento de plântulas de cafeeiro. A concentração de $1,5 \mathrm{~g} \mathrm{~L}^{-1}$ de ágar proporcionou massa fresca mais alta e maior comprimento da parte aérea enquanto o maior número de folhas foi obtido na ausência de ágar.

\section{REFERÊNCIAS}

1. ARDITT, J. Niacin biosynthesis in germinating $x$ Laeliocattlya orchid embryos and young seedlings. American Journal of Botany, v. 54, n. 3, p. 291-298, 1967.

2. BERTHOULY, M.; MICHAUX-FERRIERE, N.M. High frequency of somatic embryogenesis from Coffea canephora. Plant Cell, Tissue and Organ Culture, v. 44, n. 2, p. 169-176, 1996.

3. BERTOLUCCI, S.K.V. Micropropagação, calogênese e abordagem fitoquímica in vivo e in vitro de Tournefortia cf paniculata Cham. Lavras, 1999. 79 p. Dissertação (Mestrado em Agroquímica e Agrobioquímica) - Universidade Federal de Lavras.

4. BIEYSSE, C.; GOFFLOT, A.; MICHAUX-FERRIERE, N. Effect of experimental conditions and genotypic variability on somatic embryogenesis in Coffea arabica. Canadian Journal of Botany, v. 71, n. 11, p. 1496-1502, 1993.

5. CALDAS, L.S.; HARIDASAN, P.; FERREIRA, M.E. Meios nutritivos. In: TORRES, A.C.; CALDAS, L.S.; BUSO, J.A. (Eds.). Cultura de tecidos e transformações genéticas de plantas. Brasília: EMBRAPA-SPI/ EMBRAPA-CNPH, 1998. v.2. p. 87-132.

6. COELHO, M.C.F.; PINTO, J.E.B.P.; MORAIS, A.R.; CID, L.P.B.; LAMEIRA, O.A. Germinação de sementes de Sucupira Branca [Pterodon pubescens(Benth.)Benth] in vitro e ex vitro. Ciência e Agrotecnologia, v. 25, n. 1, p. 38-48, 2001.

7. CORDEIRO, A.T. Embriogênese somática indireta e fusão interespecífica de protoplastos em Coffea. Viçosa, 1999. 110 p. Tese (Doutorado em Fisiologia Vegetal) -Universidade Federal de Viçosa.

8. DUBLIN, P. Multiplicación vegetativa de café, hevea y cacao. In: ROCA, N.M.; MROGINSKI, L.A. (Eds.). Cultivo de tejidos en la agricultura, fundamentos y aplicaciones. Cali: CIAT, 1991. p. 577-619.

9. GEORGE, E.F. Plant propagation by tissue culture. Part. 1 The technology. 2. ed. Edington: Exegectis, 1993. 574 p.

10. JESUS, A.M.S.; CARVALHO, S.P.; PASQUAL, M.; CARVALHO, M.; TAVARES, L.V. Efeito de diferentes concentrações de BAP e dos meios básicos MS e WPM na proliferação e desenvolvimento de brotos axilares de Coffea arabica in vitro. In: SIMPÓSIO DE PESQUISAS DOS CAFÉS DO BRASIL. 3, 2003, Porto Seguro, Resumos. Brasília: Embrapa Café, 2003. p. 93.

11. LLOYD, G.; MCCOWN, B. Commercially-feasible micropropagation of mountain laurel Kalennta latifolia, by use of shoottip culture. International Plant Propagators Society Combined Proceedings, v. 30, p. 421-427, 1980.

12. MACIEL, A.L. de R; PASQUAL, M.; PEREIRA, A.R.; REZENDE, J.C. de; SILVA, A.B.; DUTRA, L.F. Embriogênese somática indireta em explantes foliares de Coffea arabica L. cv. Obatã. Ciência e Agrotecnologia, v. 27, n. 1, p. 107-116, 2003.

13. MONETTE, P.L. Micropropagation of kiwifruit using non-axenic shoot tips. Plant Cell, Tissue and Organ Culture, v. 6 , n. 1, p. 73-82, 1986.

14. MURASHIGE, T.; SKOOG, F. A revised medium for rapid growth and bioassays with tobacco tissue cultures. Physiology Plantarum, n. 15, p. 473-497, 1962.

15. PAIVA, P.D.O.; PASQUAL, M.; PAIVA, R. Efeito de concentrações de ágar e níveis de pH na propagação in vitro de crisântemo. Ceres, v. 46, n. 264, p. 141-148, 1999.

16. PASQUAL, M.; FINOTTI, D.R.; DUTRA, L.F.; CHAGAS, E.A. Cultivo in vitro de embriões imaturos de tangerineira 'Poncã' em função do pH e ágar. Revista Brasileira de Agrociência, v. 8, n. 3, p. 199-202. 2002.

17. PEREIRA, A.R.; CARVALHO, S.P. de; PASQUAL, M.; SANTOS, F.C. Embriogênese somática direta em explantes foliares de Coffea arabica cv. Acaiá Cerrado: efeito de cinetina e ácido giberélico. Ciência e Agrotecnologia, v. 31, n. 2, p. 332-336, 2007.

18. PIERIK, R.L.M. In vitro culture of higher plants. Dordrecht: Martinus Nyhoff, 1987. 344 p.

19. PIO, R.; MENDONÇA, V.; ARAÚJO NETO, S.E. de; PASQUAL, M.; FINOTTI, D.R.; DUTRA, L.F.; RAMOS, J.D. Propagação in vitro de bananeira (Musa sp.) utilizando-se diferentes concentrações de ágar. Unimar Ciências, v. 10, n. 1, p. 69-73, 2001.

20. REZENDE, J.C. de. Desenvolvimento de embriões plântulas de Coffea arabica L. oriundas da embriogênese somática direta. Lavras, 2005. 58 f. Dissertação (Mestrado em Fitotecnia) - Universidade Federal de Lavras.

21. RIBEIRO, V.G.; PASQUAL M.; RAMOS, J.D. ; CARVALHO, G.R. ; OLIVEIRA JÚNIOR, A.F. Influência do ágar e do pH sobre o cultivo 'in vitro' de embriões de laranja 'Natal'. Ceres, v. 46, n. 268, p. 587-595, 1999.

22. RIBEIRO, L.S.; PASQUAL, M.; MACIEL, A.L. de R.M.; CHAGAS E.A.; DUTRA L.F. Desenvolvimento in vitro de embriões zigóticos de Coffea arabica. Ciência e Agrotecnologia, v. 27, n. especial, p.1479-1483, 2003.

23. ROMBERGER, A.; TABOR, C.A. The Picea abies shoot apical meristem in culture. American Journal of Botany, v. 58, p. $131-140,1971$.

24. SAS Institute. Statystical Analysis System: procedures guide: version 6. Cary, 1990. 705 p.

25. SINGHA, S. Influence of two commercial agar on in vitro proliferation of 'Almey' crabapple and 'Seckel' pear. HortScience, v. 19, n. 2, p. 227-228, 1984.

26. WHITE, P.R. Further evidence on the significance of glycine, pyridoxine and nicotinic acid in the nutrition of excised tomato roots. American Journal of Botany, v. 30, p. 33-36, 1943.

27. ZAMARRIPA, A. Etude et devéloppement de l'embryogenèse somatique em milieu liquide du caféier (Coffea canephora P., Coffea arabica L. et I'hibryde Arabusta). Rennes, 1993. 191 f. Tese (Doutorado) - École Nationale Supérieure Agronomique. 
